(1)

\title{
MUTU IKAN KUWE (Gnathanodon speciosus) SEGAR YANG DIBERI PERLAKUAN CAIRAN NIRA AREN (Arenga pinnata) HASIL FERMENTASI SELAMA PENYIMPANAN
}

\section{Quality of Gnathanodon speciosus with the Treated by Arenga pinnata Fermented Liquid During Stored}

\author{
Martha L Wattimena ${ }^{*}$, Dwight. Soukotta ${ }^{1}$, Max R. Wenno' ${ }^{\mathbf{1}}$ dan Yudi Mantol ${ }^{2}$ \\ 1)Program Studi Teknologi Hasil Perikanan, Fakultas Perikanan dan ilmu Kelautan \\ Universitas Pattimura \\ 2Pelabuhan Perikanan Nusantara Tobelo, Maluku Utara \\ Koresponden: luanawattimena@gmail.com
}

\begin{abstract}
ABSTRAK
Penggunaan asam dalam pengolahan bahan makanan mempunyai peranan penting karena bersifat sebagai antimikroba. Aplikasi asam dari nira aren sudah banyak digunakan masyarakat dalam penanganan ikan untuk mempertahankan daya awet tetapi belum melakukan penelitian untuk mengetahui pengaruh daya awet ikan. Penelitian ini bertujuan untuk menganalisa pemanfaatan cairan asam nira aren (Arenga pinnata) untuk mempertahankan mutu ikan kuwe (Gnathanodon speciosus) segar. Hasil analisa keragaman menunjukkan bahwa perlakuan cairan asam nira aren (A) berpengaruh nyata terhadap nilai TMA, serta berpengaruh sangat nyata terhadap nilai $\mathrm{pH}$ sedangkan perlakuan lama penyimpanan (B) berpengaruh sangat nyata terhadap nilai TMA dan pH. Interaksi perlakuan cairan asam nira aren dan lama penyimpanan $(A B)$ berpengaruh sangat nyata terhadap nilai $\mathrm{pH}$. Hasil uji Friedman menunjukkan bahwa interaksi perlakuan cairan asam nira aren (A) dan lama penyimpanan (B) berpengaruh sangat nyata terhadap nilai bau, tekstur dan kenampakan ikan kuwe segar. Dari hasil yang diperoleh dapat disimpulkan bahwa pada parameter objektif nilai TPC, TMA, pH serta parameter subjektif yang memberikan pengaruh terbaik adalah cairan asam nira aren hasil fermentasi 9 hari.
\end{abstract}

Katakunci: Cairan hasil fermentasi,, ikan kuwe, kualitas ikan, nira aren 


\section{ABSTRACT}

The application of acids in food processing has an important role due to its antimicrobial activities. Likewise, acid derivation of palm nera has been widely used by the community in handling fish to maintain its freshness, however the research concerning its effect on fish has not been conducted yet. This study aims to analyze the application of palm nera (Arenga pinnata) in maintaining the quality of fresh Gnathanodon speciosus during storage. The results of the analysis of variance showed that the treatment of fermented palm nera $(A)$ had a significant effect on the TMA value, and had a very significant effect on the $\mathrm{pH}$ value, while the treatment of storage time (B) had a very significant effect on the TMA and $\mathrm{pH}$ values. The interaction of treatment $\mathrm{A}$ and $\mathrm{B}$ has a very significant effect on the $\mathrm{pH}$ value. The results of the Friedman test showed that the interaction of treatment $A$ and $B$ had a very significant effect on the odor, texture and appearance of fresh fish. The conclusion is the fresh fish treated by fermented palm nera and stored during 9 days obtained the best quality based on objective (TPC, TMA, pH) and subjective parameters.

Keywords: fermented liquid, fish quality, gnathanodon speciosus, palm nera, stored

\section{PENDAHULUAN}

Ikan merupakan salah satu sumber makanan yang sangat dibutuhkan karena mengandung nilai gizi yang sangat bermanfaat bagi tubuh manusia, seperti protein, lemak, berbagai vitamin dan mineral [1]. Selain itu, ikan merupakan salah satu bahan pangan yang banyak dikonsumsi masyarakat, karena mudah didapat dan harganya murah. Ikan juga merupakan salah satu bahan pangan yang sangat mudah mengalami pembusukan atau kemunduran mutu (Highly Perishable Food) karena memiliki kadar air yang cukup tinggi $(80 \%)$ dan $\mathrm{pH}$ tubuh mendekati netral $(6,4-6,8)$, akibatnya daerah-daerah yang lokasinya jauh dari sumber penangkapan maupun produksi hasil perikanan akan kesulitan mendapat ikan yang masih sangat segar [2].

Ikan Kuwe (Gnathanodon speciosus) termasuk komponen perikanan pelagis yang penting di Indonesia dan biasanya hidup pada perairan pantai dangkal, karang dan batu karang. Ikan ini juga dikenal oleh masyarakat Maluku sebagai ikan Bubara. Ikan kuwe merupakan salah satu sumber perikanan yang terdapat di perairan Maluku dan menjadi salah satu produk unggulan.

Menurut [3], penanganan ikan merupakan berbagai kegiatan atau perlakuan terhadap ikan-ikan setelah diangkat dari habitatnya, baik dalam keadaan hidup maupun mati. Penanganan merupakan kegiatan yang sangat penting, yang akan menentukan kualitas ikan selanjutnya. Adapun maksud dan tujuan penanganan adalah menghambat rantai atau memutuskan proses pembusukan untuk sementara waktu terhadap ikan-ikan yang telah ditangkap agar kesegarannya tetap terjaga saat dijual atau diproses lanjut. Cara untuk menghambat proses pembusukan ikan adalah dengan pengawetan. Proses pengolahan dan pengawetan ikan merupakan bagian penting yang bertujuan untuk mempertahankan mutu dan kesegaran ikan selama mungkin dengan cara menghambat atau mematikan mikroba pembusuk yang menyebabkan penurunan mutu maupun penyebab kerusakan ikan.

Kemunduran mutu ikan dapat diatasi dengan pemanfaatan bahan-bahan alami yang memiliki berbagai aktivitas biologi seperti antibakteri, antioksidan dan sebagainya. Penggunaan bahan alami diharapkan dapat mengurangi kecepatan kemunduran mutu ikan terutama dalam mengatasi aktivitas mikroba dan aktivitas kimia seperti penguraian protein. Penggunaan bahan alami tersebut antara lain; lidah buaya, jahe, kunyit, biji buah atung, biji buah durian, larutan hasil 
fermentasi kubis serta bahan asam (alami) seperti jeruk nipis maupun belimbing wuluh. Bahan-bahan alami yang telah diketahui manfaatnya ini merupakan bahan pengawet alami yang dapat digunakan sebagai alternatif pengganti es.

Nira aren adalah cairan yang disadap dari bunga jantan pohon aren. Cairan ini mengandung gula antara $10-15 \%$. Nira aren dapat diolah menjadi beberapa produk tradisional, salah satunya yaitu asam (biasa disebut asam cuka sageru). Fungsi asam ini sangat banyak, selain sebagai pemberi rasa dan aroma pada masakan, asam juga dapat digunakan sebagai pengawet, antiseptik, disinfektan dan obat-obatan. Hal ini dapat menyiratkan bahwa nira aren berpotensi sebagai bahan pengawet alami terhadap bahan pangan. Zat asam akan menekan reaksi yang terjadi pada saat pangan menyatu dengan oksigen sehingga dapat mencegah terjadinya pembusukan dan ketengikan [4]. Aplikasi asam dari nira aren ini sudah sering digunakan masyarakat dalam mempertahankan kesegaran dan daya awet ikan namun belum dilakukan penelitian tentang pengaruh pemberian asam dari nilai aren terhadap daya awet ikan. Penelitian ini bertujuan untuk mengetahui pemanfaatan cairan asam nira aren (Arenga pinnata) untuk mempertahankan mutu ikan kuwe (Gnathanodon speciosus) segar.

\section{METODE PENELITIAN}

\subsection{Alat dan Bahan}

Peralatan yang digunakan dalam penelitian ini adalah : Cool box, waskom, timbangan, pisau dan seperangkat alat utk analisis kimia.

Bahan yang digunakan dalam penelitian ini adalah ikan kuwe segar, dan cairan asam nira aren dan sejumlah bahan kimia untuk analisis parameter kimia.

\subsection{Prosedur Penelitian}

Prosedur penelitian adalah sebagai berikut : Ikan kuwe segar dicuci bersih dengan air mengalir, kemudian direndam selama 15 menit dalam cairan asam nira aren hasil fermentasi 6 hari, hasil fermentasi 9 hari dan hasil fermentasi 12 hari. Setelah itu dilakukan penyimpanan pada suhu ruang selama 4, 8 dan 12 jam.

\subsection{Perlakuan}

Terdapat 2 (dua) faktor perlakuan, yaitu :

\section{Faktor A (Cairan Hasil Fermentasi Nira Aren)}

$\mathrm{A}_{1 .} 6$ hari

A2. 9 hari

A3. 12 hari

\section{Faktor B (Waktu Penyimpanan)}

$\mathrm{B}_{1 .} 4$ jam

$\mathrm{B}_{2 .} 8 \mathrm{jam}$

B. 12 jam

\subsection{Pengamatan}

pengamatan secara objektif meliputi analisa TPC, TMA dan $\mathrm{pH}$, serta analisa secara subjektif yang meliputi bau, tekstur dan kenampakan, menggunakan score sheet ikan segar.

\subsection{Analisa Data}

Analisa parameter objektif (TPC, TMA, dan $\mathrm{pH}$ ) menggunakan Rancangan Acak Lengkap (RAL) dengan 2 (dua) kali ulangan, Sedangkan untuk analisa parameter subjektif (bau, rupa, tekstur) menggunakan uji friedman dan dilanjutkan dengan uji perbandingan berganda [5].

\subsection{Prosedur Analisa}

2.6.1. Analisa TPC (Total Plate Count)

Prosedur analisa TPC [6] adalah sebagai berikut : Sampel ditimbang sebanyak $25 \mathrm{~g}$, tambahkan $225 \mathrm{ml}$ larutan NaCL 0,9\% kemudian diblender selama 1-3 menit. Hasil blender dimasukkan kembali ke wadahnya dan diamkan supaya mengendap sehingga dapat dipipet. Cairan sampel hasil blender dianggap sebagai pengenceran pertama atau $10^{-1}$. Dengan menggunakan pipet steril, ambil $1 \mathrm{ml}$ cairan sampel lalu dimasukan ke dalam 9 ml larutan NaCL 0,9\% sehingga dapat diperoleh pengenceran $10^{-2}$. Kedalam 2 
cawan petridish steril dimasukan $1 \mathrm{ml}$ sampel dari masing-masing pengenceran, kemudian tuangkan sebanyak 10-15 ml plate count agar $\left(45^{\circ} \mathrm{C}\right)$. Kemudian cawan petridish digoyanggoyang membentuk angka delapan diatas permukaan yang rata sehingga diperoleh koloni bakteri yang tumbuh menyebar. Setelah agar dalam cawan petri membeku, petridish dibalik dan diinkubasi selama kurang lebih 48 jam di dalam inkubator dengan suhu $35^{\circ} \mathrm{C}$. untuk menghitung jumlah kandungan bakteri dapat dihitung berdasarkan rumus :

$\mathrm{TPC}=$ Jumlah koloni $\mathrm{x}$ 1/faktor pengenceran per cawan

\subsubsection{Analisa TMA (Trimetil Amin)}

Prosedur analisa TMA [7] adalah sebagai berikut: Sampel ditimbang sebanyak $25 \mathrm{~g}$ yang telah dipotong kecil-kecil dan dimasukan kedalam blender dan ditambahkan 75 ml TCA 7\% kemudian diblender kurang lebih selama 1 menit. Larutan hasil blender disaring dengan kertas saring sehingga diperoleh fitrat yang jernih. Larutan asam borat dipipet sebanyak $1 \mathrm{ml}$ dan dimasukan kedalam inner chamber cawan conway, kemudian dengan menggunakan pipet lain, ukur $1 \mathrm{ml}$ fitrat dan masukan kedalam auter chamber yang berlawanan sehingga larutan yang akan ditempatkan dalam outer chamber tersebut tidak akan tercampur. Tutup cawan conway pada posisi $1 / 2$ tertutup, kemudian tambahkan 0,5 ml laruan formalin kedalam outer chamber, setelah itu cawan Conway ditutup. Perlu diperhatikan sebelum ditutup sebaiknya bagian pinggir cawan conway diolesi dengan vaselin, sehingga diperoleh penutupan yang rapat (air tight). Disamping itu perlu dikerjakan blanko dengan cara yang sama dimana fitrat contoh diganti dengan larutan TCA 5\%, dan untuk setiap blanko perlu dikerjakan secara duplo. Selanjutnya cawan conway dimasukan kedalam inkubator dengan suhu $35^{\circ} \mathrm{C}$. setelah diinkubasi, titrasi asam borat dalam inner chamber cawan conway blanko, dengan larutan HCL 1/70 N hingga larutan asam borat berubah menjadi merah muda (pink). Selanjutnya berturut- turut dilakukan titrasi asam borat pada cawan conway sampel, sampai diperoleh warna merah muda (pink) yang sama dengan warna merah muda pada cawan conway blanko.

Rumus yang dapat digunakan adalah sebagai berikut :

Kadar TMA $=(\mathrm{ml}$ titrasi sampel $-\mathrm{ml}$ titrasi blanko $) \mathrm{x}$ $80 \mathrm{mgN} / 100 \mathrm{gr}$

\subsubsection{Analisa pH}

Prosedur analisa pH [8] adalah sebagai berikut: Timbang sampel yang telah dipotong kecil-kecil sebanyak 20 gram, masukkan kedalam blender dan tambahkan $40 \mathrm{ml}$ aquades (1:2), kemudian sampel tersebut diblender selama 1 menit. Setelah itu tuangkan kedalam gelas piala $100 \mathrm{ml}$, dan lakukan pengukuran $\mathrm{pH}$ dengan menggunakan $\mathrm{pH}$ meter. Tapi sebelumnya alat $\mathrm{pH}$ meter yang akan digunakan untuk mengukur sampel, harus dilakukan kalibrasi lebih dahulu dengan menggunakan larutan buffer (larutan penyangga) $\mathrm{pH} \quad 4$ dan kemudian dengan larutan $\mathrm{pH} 7$.

\section{HASIL DAN PEMBAHASAN}

\subsection{Parameter Objektif}

3.1.1. TPC

Berdasarkan hasil analisis sidik ragam menunjukkan bahwa perlakuan cairan asam nila aren (A), lama penyimpanan dan interaksi kedua perlakuan tidak berpengaruh nyata terhadap nilai TPC.

Hasil penelitian menunjukan bahwa nilai TPC terendah pada penyimpanan jam ke-4 (B $)$ berturut-turut diperoleh pada perlakuan cairan asam asam nira aren hasil fermentasi 9 hari $\left(\mathrm{A}_{2}\right)$ yaitu $1,2 \times 10^{2} \mathrm{CFU} / \mathrm{g}$, 12 hari $\left(\mathrm{A}_{3}\right)$ yaitu $2,1 \times 10^{2} \mathrm{CFU} / \mathrm{g}$ dan 6 hari $\left(A_{1}\right)$ yaitu $3,2 \times 10^{2} \mathrm{CFU} / \mathrm{g}$, sedangkan pada jam ke-8 $\left(\mathrm{B}_{2}\right)$ berturut-turut diperoleh pada perlakuan 12 hari $\left(A_{3}\right)$ yaitu $0,8 \times 10^{2} \mathrm{CFU} / \mathrm{g}$, 9 hari $\left(A_{2}\right)$ yaitu $1,5 \times 10^{2} \mathrm{CFU} / \mathrm{g}$ dan 6 hari $\left(\mathrm{A}_{1}\right)$ yaitu $2,7 \times 10^{2} \mathrm{CFU} / \mathrm{g}$. Selanjutnya pada akhir penyimpanan $\left(\mathrm{B}_{3}\right)$, untuk nilai TPC terendah diperoleh pada perlakuan $A_{3}(1,1 \mathrm{x}$ $10^{2} \mathrm{CFU} / \mathrm{g}$ ) yaitu ikan yang direndam dalam cairan asam nira aren hasil fermentasi 12 
hari, sedangkan nilai TPC tertinggi diperoleh pada perlakuan $A_{1}\left(1,2 \times 10^{3} \mathrm{CFU} / \mathrm{g}\right)$ yaitu ikan yang direndam dalam cairan asam nira aren hasil fermentasi 6 hari (Gambar 1).

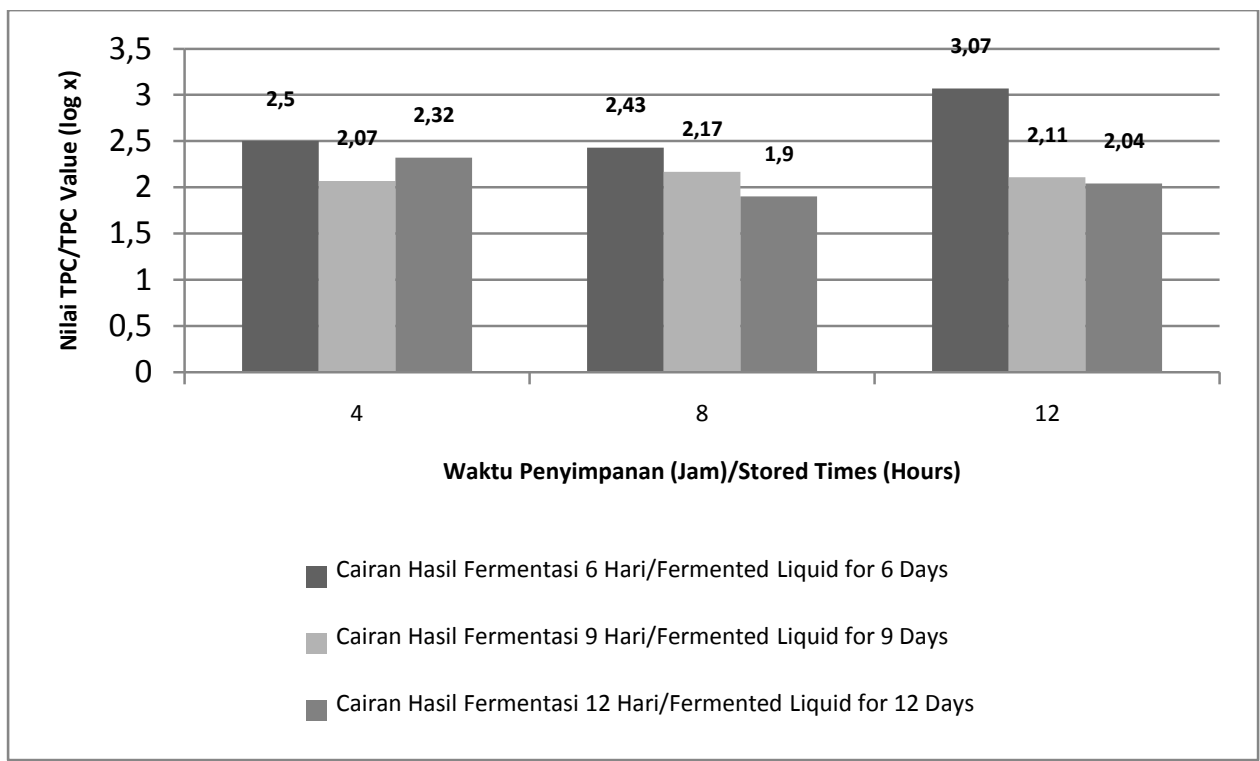

Gambar 1. Histogram Nilai TPC Ikan Kuwe yang Disimpan pada Cairan Nira Aren Hasil Fermentasi.

Fig. 1. Histogram of TPC Value of Gnathanodon speciosus Stored in Liquid Fermented from Palm Nera.

Berdasarkan hasil penelitian, perlakuan cairan nira aren hasil fermentasi untuk semua perlakuan waktu penyimpanan 4, 8 dan 12 jam menunjukkan, total bakteri ikan kuwe masih dapat diterima. Hal ini disebabkan karena cairan nira aren hasil fermentasi mengandung zat anti mikroba yang dapat menghambat pertumbuhan bakteri. Kerusakan mikrobilogis produk perikanan merupakan faktor kunci dalam menentukan kelayakan produk tertentu dan keamanannya. Standar Nasional Indonesia (SNI) untuk suatu produk tidak melebihi $5 \mathrm{x}$ $10^{5} \mathrm{CFU} / g$ [9]. Sampai pada penyimpanan jam ke-12 nilai TPC ikan kuwe yang diberi perlakuan cairan hasil fermntasi masih dibawah standar SNI dan masih layak untuk dikonsumsi. Cairan hasil fermentasi nira aren bersifat asam [10] dan dapat menghambat aktifitas bakteri pembusuk. Asam yang dihasilkan dari fermentasi cairan nira aren dapat berfungsi sebagai pengawet [11].

\subsubsection{TMA (Trimetil Amin) Hasil analisa}

keragaman menunjukkan bahwa perlakuan cairan hasil fermentasi nira aren (A) berpengaruh nyata terhadap nilai TMA ikan kuwe, sedangkan lama penyimpanan (B) berpengaruh sangat nyata terhadap nilai TMA ikan kuwe dan interaksi keduanya $(\mathrm{AB})$ tidak berpengaruh nyata terhadap TMA ikan kuwe. Berdasarkan hasil uji Beda Nyata Jujur (BNJ) diketahui bahwa perlakuan lama penyimpanan (B) untuk $B_{3}$ berbeda nyata dengan $B_{1}$ tetapi tidak berbeda nyata dengan $B_{2}$. Berdasarkan hasil penelitian menunjukkan nilai TMA jampai pada penyimpanan jam 12 masih dapat diterima, dimana ikan masih dalam keadaan segar. Nilai TMA ikan kuwe selama penyimpanan dalam cairan hasil fermentasi nila aren dapat dilihat pada Gambar 2. 


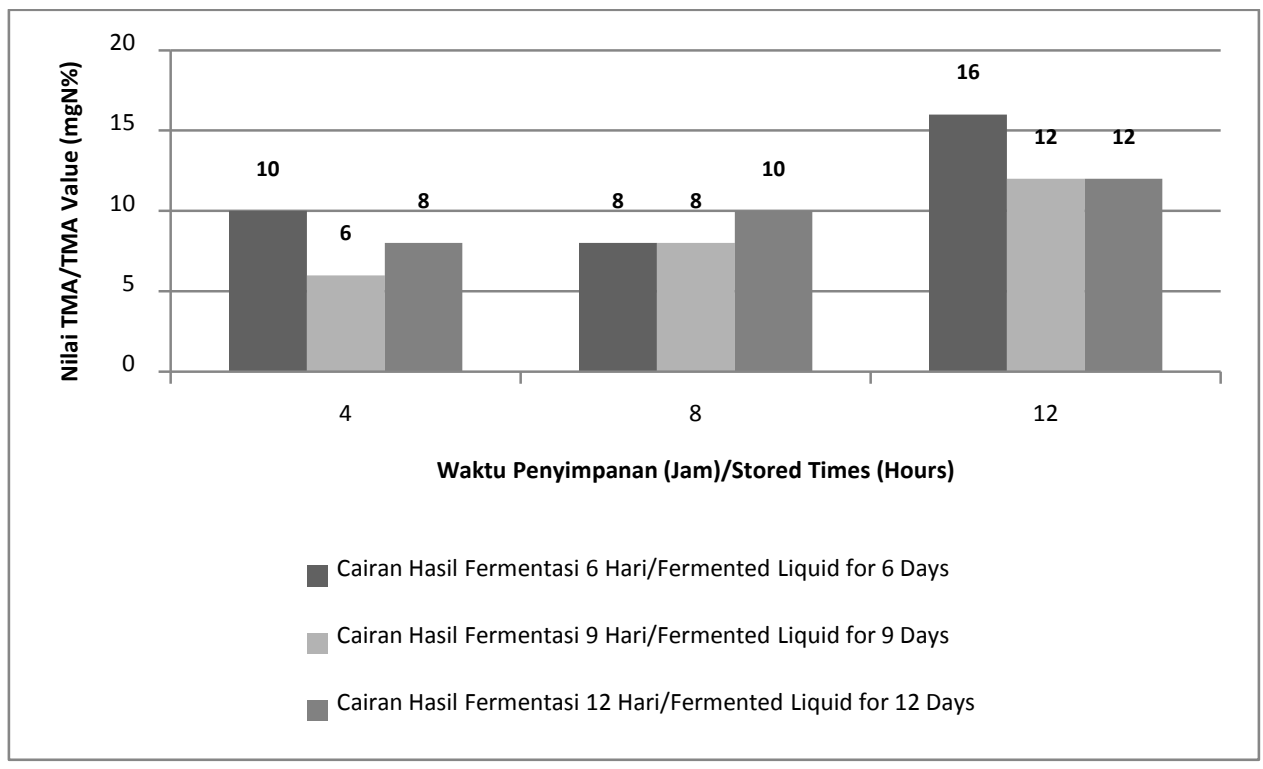

Gambar 2. Histogram Nilai TMA Ikan Kuwe yang Disimpan pada Cairan Nira Aren Hasil Fermentasi.

Fig. 2. Histogram of TMA Value of Gnathanodon speciosus Stored in Liquid Fermented from Palm Nera.

Nilai TMA ikan kuwe mengalami peningkatan seiring dengan bertambahnya waktu penyimpanan. Hal ini menunjukkan bahwa selama penyimpanan terjadi perubahan mutu ikan yang mengarah pada pembusukan yang ditandai dengan peningkatan nilai TMA. [12] mengatakan bahwa kadar TMA tergantung pada kesegaran ikan, makin mundur mutu ikan maka kadar TMA akan semakin meningkat jumlahnya. Kenaikan kadar TMA terutama disebabkan oleh aksi bakteri. Selanjutnya menurut [13], nilai TMA sebagai hasil pembusukan selain disebabkan oleh aktivitas mikroba, dapat pula disebabkan oleh proses autolisa dan oksidasi. Menurut [13], TMA merupakan hasil dekomposisi protein oleh aktivitas bakteri dan enzim, akibat dari pemecahan protein menjadi basa dengan pH 7,1-7,2. Hasil pemecahan tersebut bersifat volatile (mudah menguap) dan menimbulkan senyawasenyawa berbau busuk seperti $\mathrm{NH}_{3}, \mathrm{~N}_{2} \mathrm{~S}$, merkaptan, Kresol, Indol dan Skotol. Menurut [15] TMA adalah hasil dari reduksi TMAO oleh enzim. Pada kasus pembusukan ikan, mikroorganisme memanfaatkan atom oksigen yang disumbangkan oleh TMAO dalam kondisi aerob dan mengakibatkan peningkatan pembentukan TMA. Batas maksimum kesegaran ikan untuk parameter TMA yang masih dapat diterima ialah sebesar $30 \mathrm{mgN} / 100$ g. Dengan demikian dapat diasumsikan bahwa untuk parameter TMA, ikan kuwe dengan penambahan cairan hasil fermentasi nira aren masih dalam keadaan segar dan layak untuk dikomsumsi sampai jam ke-12 pada penyimpanan suhu ruang.

\subsubsection{Konsentrasi Ion Hidrogen (pH) Hasil analisa keragaman} menunjukkan bahwa perlakuan A (cairan hasil fermentasi nira aren) dan perlakuan B (lama penyimpanan) serta interaksi kedua perlakuan berpengaruh sangat nyata terhadap nilai pH ikan kuwe. Berdasarkan hasil uji Beda Nyata Jujur (BNJ) diketahui bahwa perlakuan cairan hasil fermentasi nira aren (A) untuk hasil fermentasi 9 hari $\left(A_{2}\right)$ berbeda nyata dengan hasil fermentasi 6 hari $\left(A_{1}\right)$ tetapi tidak berbeda nyata dengan hasil fermentasi 12 hari $\left(A_{3}\right)$ sedangkan perlakuan 
lama penyimpanan (B) untuk $\mathrm{B}_{1}$ berbeda nyata dengan $\mathrm{B}_{3}$ tetapi tidak berbeda nyata dengan $\mathrm{B}_{2}$. Ini menunjukkan bahwa cairan hasil fermentasi nira 9 hari $\left(\mathrm{A}_{2}\right)$ dan 12 hari $\left(A_{3}\right)$ memberikan pengaruh yang relatif sama terhadap perubahan nilai pH ikan kuwe. Nilai pH ikan kuwe selama penyimpanan dalam cairan nila aren hasil fermentasi dapat dilihat pada Gambar 3.

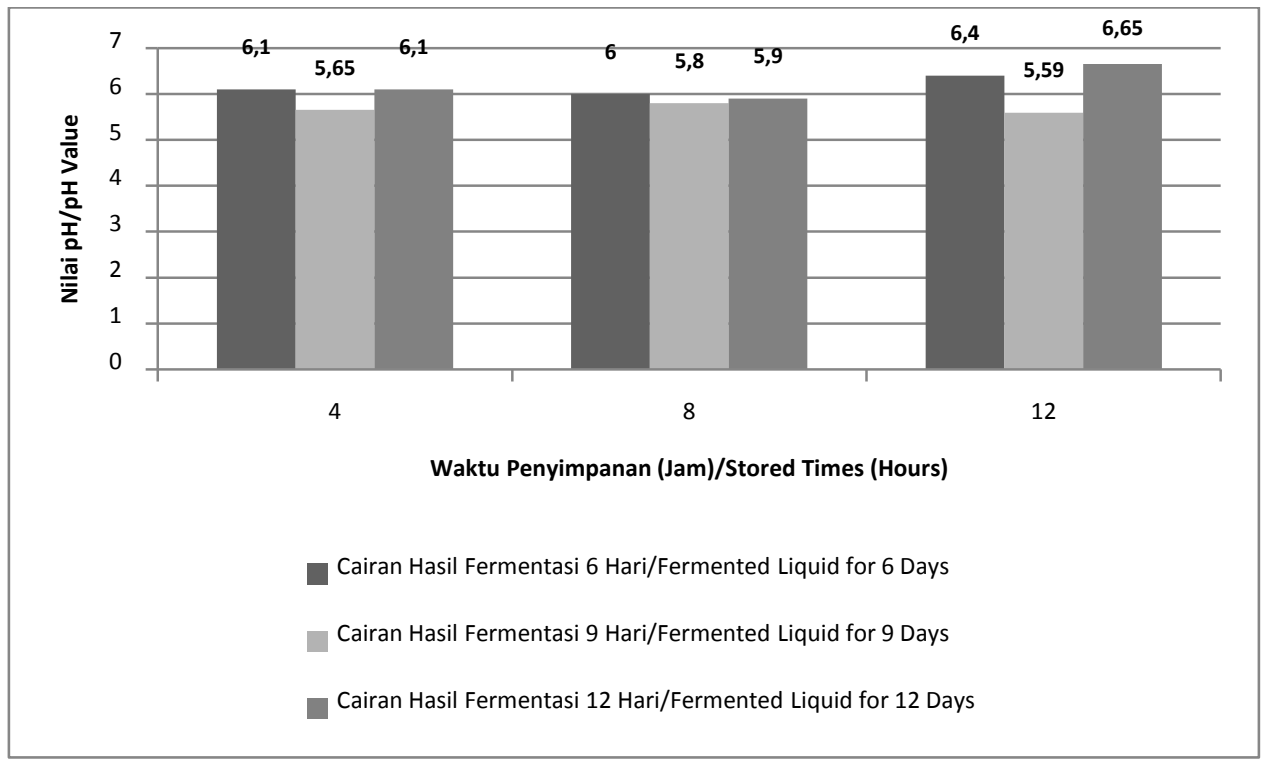

Gambar 3. Histogram Nilai pH Ikan Kuwe yang Disimpan pada Cairan Nira Aren Hasil Fermentasi.

Fig. 3. Histogram of pH Value of Gnathanodon speciosus Stored in Liquid Fermented from Palm Nera.

Data hasil analisa pH ikan kuwe segar yang direndam dalam cairan hasil fermentasi memperlihatkan bahwa nilai pH ikan kuwe dengan perlakuan cairan asam nira aren 9 hari $\left(A_{2}\right)$ menghasilkan nilai terendah diikuti cairan nira aren hasil fermentasi 12 hari $\left(\mathrm{A}_{3}\right)$ dan cairan nira aren hasil fermentasi 6 hari $\left(\mathrm{A}_{2}\right)$. Selanjutnya hasil pengamatan menunjukkan bahwa nilai pH ikan kuwe mengalami peningkatan selama penyimpanan. Terlihat pula bahwa ketiga cara perlakuan pada jam ke-4 sampai jam ke12 ikan kuwe masih dalam keadaan segar. Kondisi ini dipengaruhi oleh cairan nira aren hasil fermentasi yang digunakan, dimana nilai pH ikan kuwe untuk ketiga perlakuan cairan asam nira aren hasil fermentasi masih memiliki $\mathrm{pH}$ rendah. Nilai $\mathrm{pH}$ ikan kuwe dengan perlakuan cairan asam nira aren hasil fermentasi 9 hari menghasilkan $\mathrm{pH}$ terendah diikuti ikan kuwe dengan perlakuan cairan asam nira aren hasil fermentasi 12 hari dan cairan asam nira aren hasil fermentasi 6 hari. Selama penyimpanan $\mathrm{pH}$ ikan kuwe mengalami peningkatan seiring dengan terjadinya proses pembusukan. [2] mengatakan bahwa indeks kebusukan ikan pada kisaran nilai pH antara 6,8-7,2. Pada kondisi dimana terjadi proses pembusukan, pH ikan akan naik dengan perlahan-lahan dan dengan semakin banyak senyawa basa yang terbentuk akan semakin mempercepat kenaikan pH ikan. Selanjutnya dikatakan pula bahwa perubahan derajat keasaman $(\mathrm{pH})$ ikan disebabkan oleh adanya peningkatan jumlah senyawa-senyawa tertentu pada daging ikan sebagai hasil dari aktivitas penguraian bakteri dan enzim. Naiknya $\mathrm{pH}$ 
terutama disebabkan oleh terbentuknya amoniak dan meningkatnya kadar trimetilamin.

\subsection{Parameter Subjektif}

\subsubsection{Bau}

Hasil uji Friedman menunjukkan bahwa interaksi perlakuan penambahan cairan asam nira aren hasil fermentasi (A) dengan lama penyimpanan (B) berpengaruh sangat nyata terhadap nilai bau ikan kuwe. Sedangkan hasil uji perbandingan berganda menunjukkan bahwa perlakuan $\mathrm{A}_{2} \mathrm{~B}_{1}$ berbeda nyata dengan perlakuan $A_{1} B_{2}, A_{1} B_{3}, A_{2} B_{3}$, $A_{3} B_{2}, A_{3} B_{3}$ dan tidak berbeda nyata dengan perlakuan $A_{1} B_{1}, A_{2} B_{2}, A_{3} B_{1}$. Nilai bau ikan kuwe tertinggi pada awal dan akhir penyimpanan berturut-turut dicapai oleh ikan kuwe yang direndam dalam cairan nira aren hasil fermentasi 9 hari $\left(A_{2}\right), 6$ hari $\left(A_{1}\right)$ dan 12 hari $\left(A_{3}\right)$. Sedangkan pada jam ke-8 $\left(B_{2}\right)$ berurut-turut diperoleh pada perlakuan cairan nira aren hasil fermentasi 9 hari $\left(A_{2}\right)$, 12 hari $\left(A_{3}\right)$ dan 6 hari $\left(A_{1}\right)$. Nilai bau tertinggi pada akhir penyimpanan $\left(B_{3}\right)$ adalah pada ikan yang direndam dalam cairan nira aren hasil fermentasi 9 hari $\left(\mathrm{A}_{2}\right)$ yaitu sebesar 6,9 , sedangkan nilai bau terendah yaitu pada ikan kuwe yang direndam pada cairan nira aren hasil fermentasi 6 hari $\left(A_{1}\right)$ sebesar 5,3. Nilai Bau ikan kuwe selama penyimpanan dalam cairan nira aren hasil fermentasi dapat dilihat pada Gambar 4.

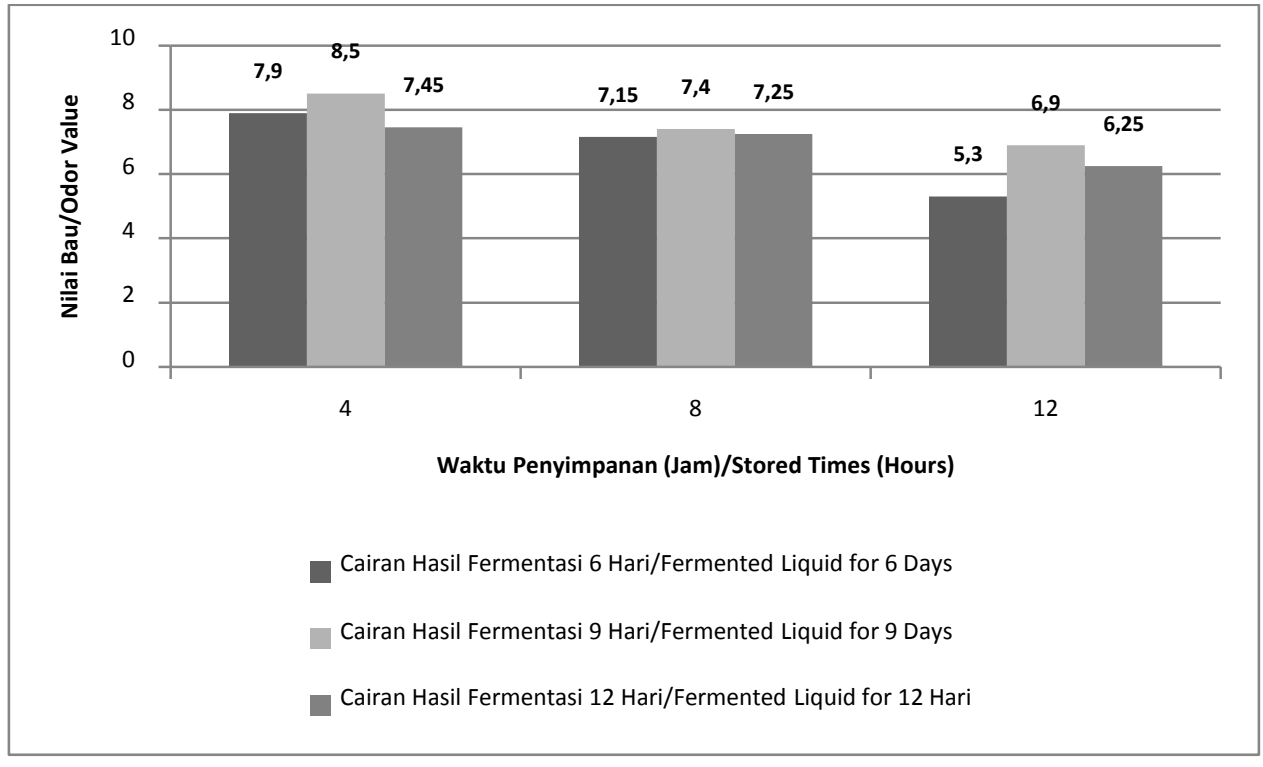

Gambar 4. Histogram Nilai Bau Ikan Kuwe yang Disimpan pada Cairan Nira Aren Hasil Fermentasi.

Fig. 4. Histogram of Odor Value of Gnathanodon speciosus Stored in Liquid Fermented from Palm Nera.

Rata-rata nilai bau ikan kuwe berkisar antara 8,15 hingga 5,3, dimana nilai bau ikan kuwe masih dapat diterima sampai lama penyimpanan 12 jam. Turunnya nilai bau ikan Kuwe ditimbulkan oleh hasil-hasil perombakan protein oleh bakteri. Semakin lama waktu penyimpanan, maka semakin tinggi pula kadar TMA dan hal ini dapat dikaitkan dengan peningkatan pembusukan produk, dimana produk-produk yang membusuk lebih banyak menghasilkan bahan-bahan yang mudah menguap [16]. 


\subsubsection{Tekstur}

Hasil uji Friedman menunjukkan bahwa interaksi perlakuan antara cairan nira aren dan lama waktu penyimpanan (AB) berpengaruh sangat nyata terhadap nilai tekstur ikan kuwe. Sedangkan hasil uji perbandingan berganda menunjukkan bahwa perlakuan $A_{2} B_{1}$ berbeda nyata dengan perlakuan $A_{1} B_{3}, A_{2} B_{3}, A_{3} B_{3}$ dan tidak berbeda nyata dengan perlakuan $A_{1} B_{1}, A_{1} B_{2}, A_{3} B_{1}$, $A_{3} B_{1}, A_{3} B_{2}$. Nilai tekstur tertinggi pada pengamatan awal (jam ke-4 $\left(B_{1}\right)$ ), berturutturut dicapai oleh perlakuan cairan asam nira aren hasil fermentasi 9 hari $\left(A_{2}\right), 12$ hari $\left(A_{3}\right)$ dan 6 hari $\left(A_{1}\right)$. Sedangkan pada jam ke-8 $\left(B_{2}\right)$ berturut-turut diperoleh pada perlakuan cairan asam nira aren hasil fermentasi 9 hari $\left(A_{2}\right), 12$ hari $\left(A_{3}\right)$ dan 6 hari $\left(A_{1}\right)$. Pada akhir penyimpanan, nilai tekstur tertinggi adalah pada ikan kuwe yang direndam dalam cairan nira aren hasil fermentasi 9 hari $\left(\mathrm{A}_{2}\right)$ yaitu sebesar 6,12, sedangkan nilai tekstur terendah yaitu pada ikan kuwe yang direndam dalam cairan nira aren hasil fermentasi 6 hari $\left(A_{1}\right)$ sebesar 5,19. Nilai tekstur ikan kuwe selama penyimpanan dalam cairan nira aren hasil fermentasi dapat dilihat pada Gambar 5.

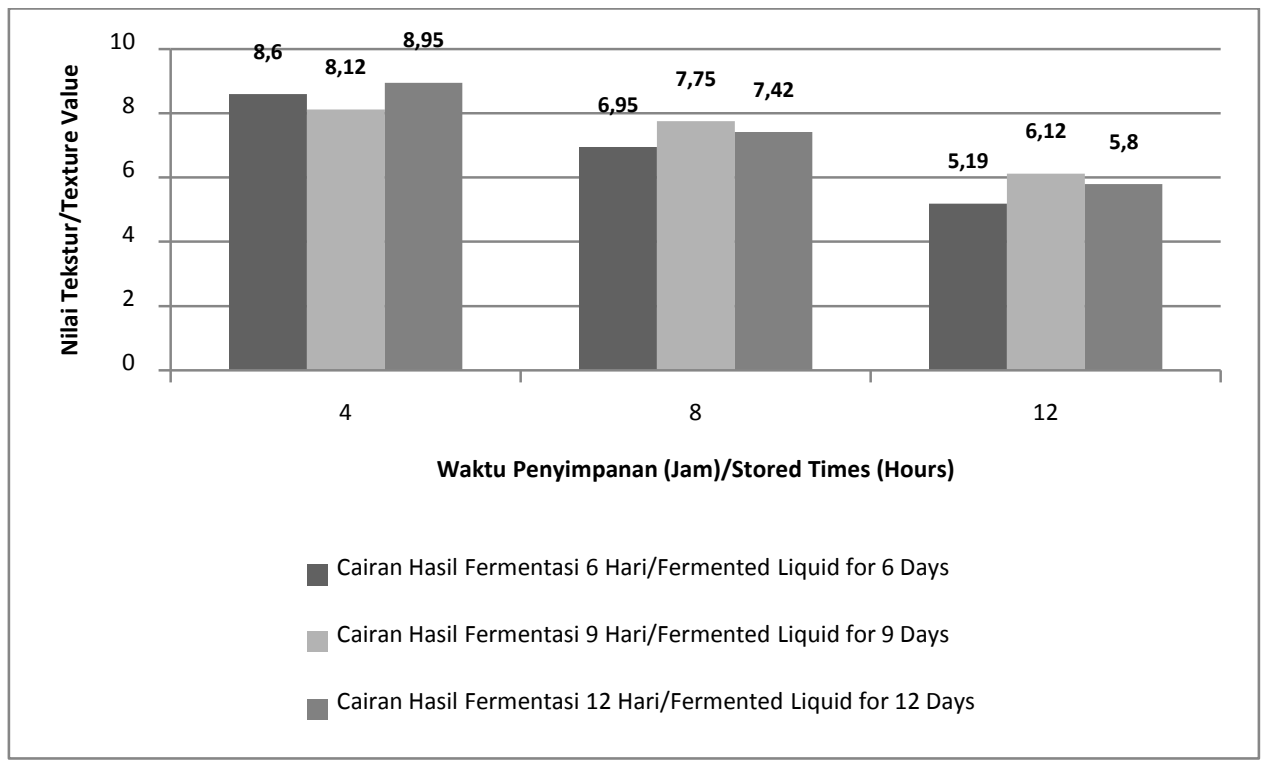

Gambar 5. Histogram Nilai Tekstur Ikan Kuwe yang Disimpan pada Cairan Nira Aren Hasil Fermentasi.

Fig. 5. Histogram of Texture Value of Gnathanodon speciosus Stored in Liquid Fermented from Palm Nera.

Rata-rata nilai tekstur ikan kuwe berkisar antara 9,12 - 5,19, dimana nilai tekstur ikan kuwe masih dapat diterima sampai lama penyimpanan 12 jam, yang berarti tekstur ikan kuwe masih baik untuk dikomsumsi. Ikan kuwe pada awal pengamatan memiliki daging yang cukup elastis yaitu bila ditekan, segera kembali seperti semula. Namun pada akhir pengamatan, elastisitas daging mulai berkurang. [17] mengungkapkan bahwa elastisitas daging ikan menunjukkan kesegerannya yang disebabkan belum terputusnya benang-benang miofibril daging. Dikemukakan pula bahwa pada ikan yang sudah busuk, benang-benang miofibril tersebut terputus dan dinding sel daging ikan telah rusak sehingga daging kehilangan 
elastisitasnya. Selama penyimpanan, produk perikanan mengalami kerusakan seperti oksidasi lemak, perubahan warna, perubahan protein, aktivitas enzim dan bakteri yang kesemuanya akan mempengaruhi rupa, bau dan tekstur [18]. Menurut [11], asam berfungsi untuk mempertahankan tekstur dan mencegah terjadinya pembusukan akibat mikroba.

\subsubsection{Kenampakan}

Hasil uji Friedman menunjukkan bahwa interaksi perlakuan cairan nira aren dan lama penyimpanan berpengaruh sangat nyata terhadap nilai kenampakan ikan kuwe. Sedangkan hasil uji perbandingan berganda menunjukkan bahwa interaksi perlakuan $\mathrm{A}_{2} \mathrm{~B}_{1}$ berbeda nyata dengan interaksi perlakuan $A_{1} B_{3}, A_{2} B_{3}, A_{3} B_{3}$ dan tidak berbeda nyata dengan interaksi perlakuan $A_{1} B_{1}, A_{1} B_{1}$, $A_{1} B_{2}, \quad A_{2} B_{2}, A_{3} B_{1}, A_{3} B_{2}$. Nilai kenampakan tertinggi pada jam ke-4 (B $\left.B_{1}\right)$ berturut-turut diperoleh pada perlakuan cairan asam nira aren hasil fermentasi 9 hari $\left(A_{2}\right), 6$ hari $\left(A_{1}\right)$ dan 12 hari $\left(A_{3}\right)$. Sedangkan pada jam ke-8 $\left(B_{2}\right)$ berturut-turut diperoleh pada perlakuan cairan asam nira aren hasil fermentasi 12 hari $\left(A_{3}\right), 9$ hari $\left(A_{2}\right)$ dan 6 hari $\left(A_{1}\right)$. Pada akhir penyimpanan, nilai kenampakan tertinggi adalah pada ikan kuwe yang direndam dalam cairan nira aren hasil fermentasi 9 hari $\left(\mathrm{A}_{2}\right)$ yaitu sebesar 6,3, sedangkan nilai kenampakan terendah yaitu pada ikan yang direndam dalam cairan asam nira aren hasil fermentasi 6 hari (A1) sebesar 4,8. Nilai kenampakan ikan kuwe selama penyimpanan dalam cairan nira aren hasil fermentasi dapat dilihat pada Gambar 6.

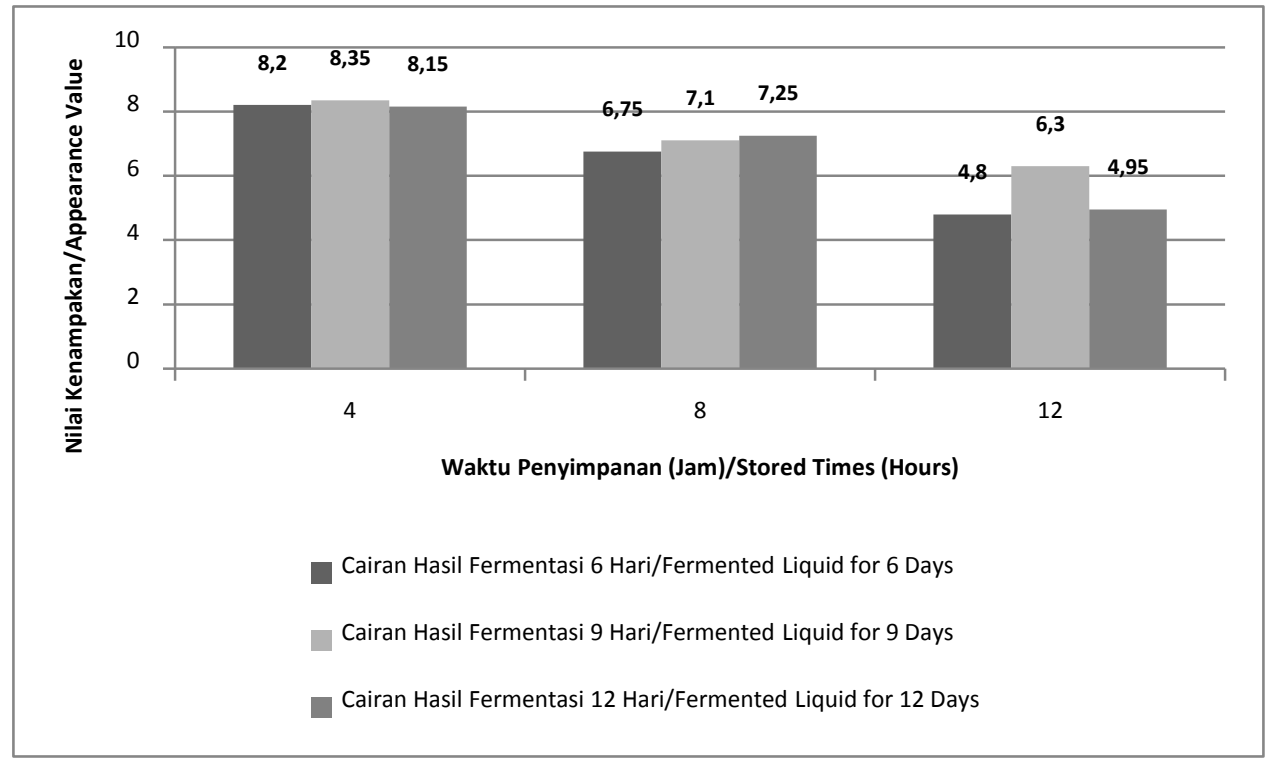

Gambar 6. Histogram Nilai Kenampakan Ikan Kuwe yang Disimpan pada Cairan Nira Aren Hasil Fermentasi.

Fig. 6. Histogram of Apperance Value of Gnathanodon speciosus Stored in Liquid Fermented from Palm Nera.

Rata-rata nilai kenampakan ikan kuwe berkisar antara 8,3 - 4,8, dimana nilai kenampakan ikan kuwe masih dalam keadaan yang dapat diterima oleh penelis dan dapat diterima sampai lama penyimpanan 12 jam.
Menurut [18], selama penyimpanan produk perikanan akan mengalami kerusakan seperti oksidasi lemak, perubahan warna, perubahan protein, aktivitas enzim dan bakteri yang juga dapat mempengaruhi kenampakan ikan. 
Peredaman dalam cairan nira aren menyebabkan warna memudar sejalan dengan semakin bertambahnya waktu penyimpanan, sehingga mempengaruhi tingkat penerimaan penelis terhadap parameter kenampakan ikan. [14] mengatakan bahwa kenampakan dari suatu produk perikanan merupakan salah satu kunci dalam menentukan kualitas suatu bahan atau produk. Asam berfungsi sebagai penguat tekstur sehingga mampu mempertahankan kenampakan pangan, meningkatkan warna, dan cita rasa makanan [11].

\section{KESIMPULAN}

Dari hasil yang diperoleh dapat disimpulkan bahwa perlakuan cairan nira aren hasil fermentasi 9 hari lebih baik dari kedua perlakuan yang lain berdasarkan nilai parameter objektif yaitu TPC, TMA dan $\mathrm{pH}$ serta parameter subjektif yaitu bau, tekstur dan kenampakan.

\section{DAFTAR PUSTAKA}

[1] Supraptiningsih E. dan Rorong VV. 2008. Pengolahan Hasil Perikanan. PT Intan Sejati. Klaten.

[2] Ilyas S. 1972. Pengantar Pengolahan Ikan. Lembaga Teknologi Perikanan. Jakarta.

[3] Suprapati ML. 2002. Teknologi Pengolahan Pangan Bandeng Asap. Kanisius. Yogyakarta.

[4] Juhain A. 1992. Balai Penelitian dan Pengembangan Industri Banjar Baru.

[5] Wayne DA. 1989. Statistic Non Parametric, Alih Bahasa: Kuncoro W. Gramedia. Jakarta.

[6] Fardiaz S. 2001. Analisis Mikrobiologi Pangan. Jakarta. PT Raja Grafindo Persada.

[7] [AOAC]. 2005. Official methods of analysis of the association of analytical chemist. Virginia USA: association of official analytical chemist, Inc.
[8] Hebard CE., Flick GJ. and Martin RE. 1982. Occurrence and significance of trimethylamine oxide and its derivatives in fish and shellfish. In: Martin RE., Flick GJ., Hebard, CE., Ward DR. (ed.) Chemistry and biochemistry of marine food products. AVI Publ., Westport. Connecticut. p. 149-304.

[9] [BSN] Badan Standarisasi Nasional. 2010. SNI Jumlah Koloni Bakteri Ikan Segar. Jakarta

[10] Leasa H. dan Matdoan MN. 2015. Pengaruh lama fermentasi terhadap total asam cuka aren (Arenga pinnata Merr.). Biopendix, Jurnal Biologi, Pendidikan dan Terapan, 1(2): 140145.

[11] Baharuddin, Syahidah dan Yatni N. 2008. Penentuan mutu cuka nira aren ((Arenga pinnata) berdasarkan SNI 01-4371-1996. Jurnal Perennial, 5(1): 31-35.

[12] Murtini JT., Riyanto R., Priyanto N. dan Hermana I. 2014. Pembentukan formaldehid alami pada beberapa jenis ikan laut selama penyimpanan dalam es curai. Jurnal Pascapanen dan Bioteknologi Kelautan dan Perikanan, 9(2): 143-151.

[13] Fraizier WE and westhoff DC. 1979. Food Microbiology. MC. Graw Hill Publishing Co.Ltd. New Dehli.

[14] Desroiser NW. 1977. Element of Food Technology. Avi Publishing Company Inwesport Connecticut.

[15] Suprayitno E. 2020. Kajian kesegaran ikan di pasar tradisional dan modern kota Malang. Journal of Fisheries and Marine Research, 4(2): 289-295.

[16] Rahayu S dan Murdiani NS. 1982. Laporan penelitian Teknologi No. 17.

[17] Kanoni S. 1990. Kimia dan Teknologi Pengolahan Ikan. Pusat Antar Universitas. Universitas Gajah Mada. Yogyakarta.

[18] Zaitsev VI., Kizevetfer, Laganov I, Podsewlou V, 1969. Fish Curing And Processing. Translated From The Russian By A. Merindol. Mr. Publisher. Moscow. 